\title{
C-Cell Hyperplasia and Medullary Thyroid Carcinoma: Clinicopathological and Genetic Correlations in 66 Consecutive Patients
}

Serge Guyétant, M.D., Nicolas Josselin, M.D., Fréderique Savagner, M.D., Vincent Rohmer, M.D., Sophie Michalak, M.D., Jean-Paul Saint-André, M.D.

Department of Pathology (SG, NJ, SM, J-PS-A), Department of Biochemistry and Molecular Biology, Inserm EMI-U 0018 (FS), and Department of Endocrinology-Médecine C (VR), Centre Hospitalier

Universitaire, Angers, France

Routine calcitonin (CT) assay programs and genetic testing for $R E T$ proto-oncogene mutations have consistently modified the management and understanding of C-cell proliferative disorders. We report a series of 66 consecutive patients with C-cell hyperplasia $(\mathrm{CCH})$ or medullary thyroid carcinoma (MTC) observed in our institution within an 8-year time period. All the patients had a preoperative basal CT assay and an RET proto-oncogene sequencing. Seventeen patients (F-M ratio: 8:9, mean age: 29.7 y) had a multiple endocrine neoplasia Type 2: 3 children < 10 years of age had CCH only, and 14 patients had an MTC, with neoplastic CCH in 10/14 cases. Twenty-seven patients (F-M ratio: 18:9, mean age: 56.6 y) had a sporadic MTC, with physiological CCH in 8 and neoplastic CCH in 3 cases. Twenty-two men (mean age: 46.2 y) had CCH only (physiological CCH in 17 men and neoplastic CCH in 5). We conclude that (1) clinical and pathological characteristics (familial MTC, tumor multifocality, neoplastic $\mathrm{CCH}$ ) usually associated with hereditary MTC may be misleading and that on the contrary, RET sequencing gives no false positive result; (2) sporadic neoplastic $\mathrm{CCH}$ accompanies (and probably precedes) a number of sporadic MTC; and (3) women presenting with a sporadic elevated basal CT have a $100 \%$ risk of having an MTC (15/15), but this risk is 3 -fold less in men (31\%), who will most often have CCH only (69\%).

Copyright () 2003 by The United States and Canadian Academy of Pathology, Inc.

VOL. 16, NO. 8, P. 756, 2003 Printed in the U.S.A.

Date of acceptance: May 1, 2003.

Address reprint requests to: Serge Guyétant, M.D., Laboratoire d'Anatomie Pathologique, CHRU Tours - Hôpital Trousseau, 37044 Tours Cedex 1, France; fax: 33-2-4747-4622; e-mail: guyetant@med.univ-tours.fr. DOI: 10.1097/01.MP.0000081727.75778.0C
KEY WORDS: C-cell hyperplasia, Gender, Medullary thyroid carcinoma, Microcarcinoma, $R E T$.

Mod Pathol 2003;16(8):756-763

Medullary thyroid carcinoma (MTC) is a rare neoplasm, which is hereditary in $25 \%$ of the cases, in multiple endocrine neoplasia Type 2 (MEN 2) families (1). During the past 10 years, two major tests have modified the current approach and presentation of MTC. First of all, the development of calcitonin (CT) screening programs in routine endocrinological practice has proven to be effective in the early detection of a number of MTCs (2-4). As a consequence, pathologists have been confronted with a dramatic increase in micro-MTC diagnosis ratio, as illustrated by recent series (5-7). On the other hand, this routine biological screening has also been responsible for the detection of an increasing number of patients presenting with $\mathrm{C}$-cell hyperplasia $(\mathrm{CCH})$ only $(3,8)$, in which thyroidectomy might be considered unjustified. Moreover, a highly sensitive and specific genetic test is now available to identify the germline mutations of the proto-oncogene RET in affected members of MEN 2 families. In MEN 2, MTC is characterized by a high penetrance $(>90 \% ; 9)$, and since 1997 there has been a consensus that the decision to perform a thyroidectomy should be based predominantly on the result of genetic testing (10). Therefore, affected children with a positive genetic testing are now often treated at a preneoplastic stage, called neoplastic CCH or in situ MTC $(1,11,12)$.

In this study, we describe the clinicopathologic features of a series of MTC and CCH cases with complete biological and genetic testing, with emphasis on the practical consequences of these new diagnosis approaches in current diagnostic pathology and on the correlations between the various C-cell proliferative processes and clinical presentation. 


\section{MATERIALS AND METHODS}

Ninety-seven consecutive patients, excluding consultation cases, with an MTC or CCH diagnosis were retrieved in our pathology department files over a period of 8 years (from 1993 to 2000), representing $2.9 \%$ of 3342 thyroid pathological specimen examined during this time period. Thirty-one patients with nontotal thyroidectomy, with no or partial genetic testing, or with incomplete biological or clinical data were excluded.

\section{Clinical, Biological and Genetic Studies}

The medical records were reviewed for the following data: age, sex, medical complaint, preoperative levels of calcium, free thyroxin, thyroid stimulating hormone and thyroid auto-antibodies, associated thyroid pathology, and familial screening. Serum CT was measured by an immunometric assay using two antibodies (ElsahCT; Cis-Bio international, Gif sur Yvette, France), and basal CT values $\leq 10 \mathrm{pg} / \mathrm{mL}$ were considered normal, according to the French Calcitonin Tumors Study Group (GETC; 13). In patients who underwent a pentagastrin stimulation test, the response was expressed as the peak CT value after injection and was considered normal if this peak did not exceed $15 \mathrm{pg} / \mathrm{mL}$ in children $<15$ years of age and $30 \mathrm{pg} / \mathrm{mL}$ in adults (14). All the patients gave their consent to a germline mutation testing of the RET proto-oncogene. DNA was extracted from peripheral blood, then amplified by polymerase chain reaction. A negative result (no mutation) was considered after examination of exons $8,10,11,13,14,15$, and 16. The diagnosis and subclassification of MEN 2 was made according to the international consensus guidelines (9).

\section{Pathological Study}

All the specimens were submitted to the same routine pathological procedure that has been previously described (15) and were reviewed by two pathologists (SG, NJ) without knowledge of the clinical history and genetic status. Briefly, the thyroid gland was fixed in formalin, then horizontally sliced, and each section was embedded in paraffin. Serial $5-\mu \mathrm{m}$ sections of each block were used for routine stains (hematoxylin-eosin-saffron) and immunohistochemistry. Deparaffinized sections of all blocks were stained for CT (polyclonal rabbit anti-CT serum at 1/1000 dilution; DAKO SA, Paris, France). First of all, hematoxylin-eosin-saffron stained slides were screened to identify "neoplastic $\mathrm{CCH}$," as proposed by Perry et al. (11). Neoplastic $\mathrm{CCH}$ was recognized by the presence of clusters of intrafollicular C-cells, easily identified on routine stains, made of mildly to moderately atypical cells with nuclear pleomorphism, differing from adjacent follicular cells and resembling those identified in an MTC. In a second step, CT-stained slides were screened, and for each thyroid lobe the slide with the highest estimated C-cell density was submitted to semiquantitative evaluation: the number of lowpower fields (LPF) at $100 \times$ magnification containing $>50 \mathrm{C}$-cells (field area: $1.93 \mathrm{~mm}^{2}$ ) and the peak number of C-cells in one LPF were determined. A $\mathrm{CCH}$ diagnosis was made when at least three LPF containing $>50$ CT-immunostained cells were observed in one thyroid (16). According to Perry et al.(11), cases fulfilling the above-mentioned quantitative $\mathrm{CCH}$ criteria, but made of morphologically bland C-cells on routine slides, were diagnosed as "physiologic CCH." In a third step, we subclassified physiologic $\mathrm{CCH}$ according to the main growth pattern into focal, diffuse, and nodular forms, as previously proposed by Kaserer et al. $(3,7)$. Focal CCH corresponded to a segmental proliferation pattern of C-cells in the thyroid follicle, diffuse $\mathrm{CCH}$ was diagnosed when C-cells formed circumferential intrafollicular collars, and in nodular $\mathrm{CCH}$, C-cells formed clusters completely obliterating follicular lumens. In the differential diagnosis between $\mathrm{CCH}$ (mainly nodular physiologic $\mathrm{CCH}$ and neoplastic $\mathrm{CCH}$ ) and early micro-MTC, we considered the extension of C-cells through defects in the follicular basal lamina and the infiltration of the thyroid interstitium as malignancy criteria (17). Also, the existence of isolated infiltrating C-cells in a fibrous stroma and the identification of amyloid deposits were strong diagnostic criteria for micro-MTC. In a few cases, immunohistochemistry with anticollagen Type IV antibody (monoclonal anticollagen IV antibody at 1/150 dilution; DAKO SA, Paris, France) was applied to identify defects and/or reduplications of basal membrane, producing a microlobular or trabecular configuration in early MTC, as described by McDermott et al. (18). In contrast, we did not rely on cytological atypia for micro-MTC diagnosis, because it can be observed in neoplastic $\mathrm{CCH}$ (11).

\section{Statistical Analysis}

Statistical analysis was performed with Statview*SE+ Graphics (Abacus Concept, Inc., Chicago, IL). Either the Student's $t$ test or, when necessary, a nonparametric test (Mann-Whitney) were applied to compare means, and the $\chi^{2}$ test was used to compare frequency distributions. $P$ values of $<.05$ were considered statistically significant.

\section{RESULTS}

Sixty-six patients (26 women, 40 men; sex ratio, $\mathrm{F}-\mathrm{M}=0.65), 5$ to 79 years old $($ mean $=46.2 \mathrm{y})$ were 
operated on in our institution between 1993 and 2000 with a consecutive CCH or MTC diagnosis. Forty-three patients sought consultation for a diffuse goiter or nodular thyroid disease, and 18 patients were potential MEN 2 carriers due to a prior familial MTC (17 cases) or to a concomitant bilateral phaeochromocytoma (1 case). Five patients presented with an isolated hypercalcitoninemia (CT $>10 \mathrm{ng} / \mathrm{mL}$ ) identified after CT assay for a number of conditions such as a suspect cervical lymph node, diarrhea, elevated blood pressure, or vague recurrent symptoms of discomfort and flush. In most patients (59/66 [89.4\%]), a C-cell disorder was suspected before surgery, because of either an elevated CT (41 patients), a suspected diagnosis of MEN 2 (4 patients), or both (14 patients). Consequently, a complete thyroidectomy was performed. Seven of 66 cases $(10.6 \%)$ were fortuitous (normal CT level and no MEN 2 familial context) pathological discoveries on thyroidectomy specimen from patients operated on for another thyroid disease. In these cases, the thyroid glands were subsequently wholly included in paraffin for complete examination. The main pathological and clinical data are summarized in Table 1 and Table 2.

\section{Clinicopathological Data According to Genetic Status}

\section{MEN 2 Carriers}

Seventeen patients ( 8 women, 9 men) belonging to nine families were MEN 2 carriers with a documented RET mutation: 3 patients were members of MEN 2A families, whereas 14 patients belonged to fMTC (familial MTC) families. The RET mutation and MEN 2 subtype are shown in Table 3. Three patients were index cases presenting with an elevated CT and a nodular goiter (2 cases) or a bilateral phaeochromocytoma (1 case). Pathological examination revealed multiple MTC associated with neoplastic $\mathrm{CCH}$ in two cases and without $\mathrm{CCH}$ in one. Fourteen patients were relatives of MEN 2 index cases. Seven patients were children $<15$ years of age (range, 5-12 y; mean, 7.9 y). Five of them had elevated basal CT levels, and two had only an abnormal pentagastrin test. Four children (6 to $12 \mathrm{y}$ old) already had one or several micro-MTCs, associated with neoplastic $\mathrm{CCH}$ in three cases and diffuse $\mathrm{CCH}$ in one. On the other hand, three children (5 to $10 \mathrm{y}$ old) presented with $\mathrm{CCH}$ alone (diffuse $\mathrm{CCH}$ in 2 cases and focal $\mathrm{CCH}$ in 1 case). Seven patients were adults, 28 to 74 years old (mean: $42 \mathrm{y}$ ), with an elevated basal CT in four cases, an abnormal pentagastrin test only in two cases, and both a normal basal and stimulated CT in one case. All of them had multiple micro-MTCs with associated neoplastic $\mathrm{CCH}$ in five cases and no $\mathrm{CCH}$ in two cases.

\section{Sporadic Cases}

Forty-six patients (18 women, 28 men; sex ratio F-M: 0.64 , mean age: 52.3 y) presenting with neither RET mutation nor family history of MEN 2 or MTC were included in this series.

Twenty-seven patients (18 women, 9 men; sex ratio F-M: 2) had a sporadic MTC (micro-MTC in 17 cases). The tumor was unique in 23 cases (including 12 micro-MTC), 3 patients had two MTC in the same thyroid lobe, and 1 patient had a bilateral MTC (two tumors in both lobes). In women, 17/18 tumors were unique, with no $\mathrm{CCH}$ (14 cases) or focal $\mathrm{CCH}$ (4 cases). In men, six patients had a unique MTC, with no $\mathrm{CCH}$ in two cases, diffuse $\mathrm{CCH}$ in two cases, nodular $\mathrm{CCH}$ in one case, and neoplastic $\mathrm{CCH}$ in one case. Three male patients had multiple micro-MTC, associated with diffuse $\mathrm{CCH}$ in one case and neoplastic $\mathrm{CCH}$ in two cases.

Nineteen men, aged from 28 to 66 years (mean: $46.2 \mathrm{y}$ ), had a sporadic CCH without MTC (sporadic $\mathrm{CCH}$ only). There were 3 focal, 7 diffuse, 4 nodular, and 5 neoplastic $\mathrm{CCH}$. No woman had $\mathrm{CCH}$ only. Overall, CCH was present in 30/46 sporadic cases and was almost always bilateral (29/30 cases).

\section{Undetermined Cases}

In three patients, a thyroidectomy was performed on the basis of an abnormal basal CT discovered in a first-degree relative of an index MTC case. In each family, only the index case had an MTC (unique MTC in 2 patients, 2 micro-MTC in 1 case), and no RET mutation was identified in the seven abovementioned exons in the family. The three patients

TABLE 1. Main Clinical and Biological Data in MEN 2 and Sporadic Cases

\begin{tabular}{|c|c|c|c|c|c|}
\hline & Number & Age (mean) & $\begin{array}{l}\text { Gender } \\
(\mathrm{F} / \mathrm{M})\end{array}$ & $\begin{array}{l}\text { BasalCT }(\mathrm{ng} / \mathrm{mL}) \\
(\text { median })\end{array}$ & $\begin{array}{c}\text { Stimulated CT }(\mathrm{ng} / \mathrm{mL}) \\
(\text { median })\end{array}$ \\
\hline MEN 2 & 17 & $5-74(29.7)$ & $8 / 9$ & $0-567(13)$ & $14-4794(54.5), n=14$ \\
\hline MEN 2A & 3 & $6-33(15.3)$ & $2 / 1$ & $7-23(14.5)$ & $14-60(37), n=2$ \\
\hline fMTC & 14 & 5-74 (32.7) & $6 / 8$ & $0-567(13)$ & $18-4794(61), n=12$ \\
\hline Sporadic C-cell disease & 46 & $28-79(52.3)$ & $18 / 28$ & $3-12350(20.5)$ & $29.6-2700$ (121), $n=25$ \\
\hline sMTC only & 16 & $38-79(56.0)$ & $14 / 2$ & $3-12350(255)$ & $108-2700$ (245), $n=5$ \\
\hline $\mathrm{sMTC}+\mathrm{CCH}$ & 11 & $46-72(57.5)$ & $4 / 7$ & $3-1150(21)$ & $44-130$ (116), $n=3$ \\
\hline CCH only & 19 & $28-66(46.2)$ & $0 / 19$ & 8-51 (15) & $29.6-188(114), n=17$ \\
\hline Unclassified cases & 3 & $36-60(45)$ & $0 / 3$ & $17-53(23)$ & $41-85(67), n=3$ \\
\hline
\end{tabular}

BasalCT = basal calcitonin level; stimulated CT = peak calcitonin level after pentagastrin infusion test. 


\begin{tabular}{|c|c|c|c|c|}
\hline \multirow[b]{2}{*}{ Clinical Setting } & \multicolumn{4}{|c|}{ Diagnosis } \\
\hline & $\begin{array}{c}\text { Sporadic MTC } \\
(+/-\mathrm{CCH})\end{array}$ & $\begin{array}{c}\text { Sporadic CCH } \\
\text { only }\end{array}$ & MEN 2 & $\begin{array}{l}\text { CCH Only, } \\
\text { Unclassified }\end{array}$ \\
\hline \multicolumn{5}{|l|}{ Fortuitous ( $\mathrm{n}=48$ ) } \\
\hline Men $(\mathrm{n}=29)$ & 9 & 19 & 1 & 0 \\
\hline Women (19) & 18 & 0 & 1 & 0 \\
\hline \multicolumn{5}{|c|}{ Probable MEN $2(\mathrm{n}=18)$} \\
\hline Men $(\mathrm{n}=11)$ & 0 & 0 & 8 & 3 \\
\hline Women $(\mathrm{n}=7)$ & 0 & 0 & 7 & 0 \\
\hline
\end{tabular}

$\mathrm{NB}=$ unclassified cases represent $\mathrm{CCH}$ cases in patient with a normal RET oncogene sequencing but with a previous MTC case in the family.

TABLE 3. RET Mutation Analysis Result in the Nine MEN 2 Families

\begin{tabular}{ccl}
\hline $\begin{array}{c}\text { Affected Codon and } \\
\text { Amino-Acid Exchange }\end{array}$ & Exon & MEN 2 Subclassification \\
\hline C634Y & 11 & MEN 2A \\
C634S & 11 & MEN 2A \\
C634S & 11 & MEN 2A \\
V804M F & 14 & fMTC \\
S891A & 15 & fMTC \\
S891A & 15 & fMTC \\
S891A & 15 & fMTC \\
V804 \& R844L & 14 & fMTC \\
S891A & 15 & fMTC \\
\hline
\end{tabular}

were men aged from 36 to $60 \mathrm{y}$, with physiological $\mathrm{CCH}$ of various degrees ( 1 focal, 1 diffuse, and 1 nodular) with neither neoplastic CCH nor MTC.

\section{Comparative Pathological Data}

Sporadic versus Hereditary MTC

Forty-one patients had an MTC, among which 27 were sporadic MTC and 14 were MEN 2-associated MTC. The main clinicopathological differences between these two groups are summarized in Table 4. Patients with a hereditary MTC were significantly younger than patients with a sporadic MTC $(P=$ .0002), but this difference was biased by the fact that $11 / 14$ MEN 2 cases were identified by genetic screening. Only 3/14 patients were MEN 2 index cases, 33 to 69 years old (mean 51.7 y), with no significant age difference with sporadic cases. The presence of a previous MTC in the family was strongly associated with MEN $2(P=.0001)$. In comparison with sporadic cases, hereditary MTC were most often bilateral and multifocal $(P=.0001$ for both) and associated with $\mathrm{CCH}(P=.005)$. A neoplastic $\mathrm{CCH}$ was preferentially associated with hereditary MTC $(P=.0003)$.

\section{CCH Quantification and Classification}

Forty-seven patients had $\mathrm{CCH}$, which was morphologically classified as focal in 9 cases, diffuse in 14 cases, nodular in 6 cases, and neoplastic in 18 cases (Figs. 1-5). Quantitative data are summarized in Table 5. Among physiological CCH cases, there was a significant increase in C-cell density, estimated by the highest number of LPF containing $>50$ C-cells on one slide, between focal and diffuse CCH $(P=.033)$, and between diffuse and nodular $\mathrm{CCH}(P=.026)$. There was also a tendency towards an increase in the peak C-cell number in one LPF from focal to diffuse and to nodular $\mathrm{CCH}$, although it did not reach a statistical significance $(P=.13$ and $P=.08$, respectively). When estimated by the highest number of LPF containing $>50 \mathrm{C}$-cells on one slide, there was no significant difference between physiological and neoplastic $\mathrm{CCH}$. However, the latter contained a significantly higher peak $\mathrm{C}$-cell number per LPF than physiological CCH as a whole $(P=.0007)$. This difference was not significant between nodular $\mathrm{CCH}$ and neoplastic $\mathrm{CCH}$. There was no statistical difference in preoperative CT level according to the different $\mathrm{CCH}$ subtypes, and there was no significant association between the presence of a chronic lymphocytic thyroiditis (6 cases) and the identification of a $\mathrm{CCH}$.

TABLE 4. Comparison between Sporadic MTC and MEN 2-Associated MTC

\begin{tabular}{|c|c|c|c|c|c|c|c|c|}
\hline & Age (mean) & $\begin{array}{c}\text { Gender } \\
(\mathrm{F} / \mathrm{M})\end{array}$ & Bilaterality & Multifocality & \multicolumn{3}{|c|}{ Physiologic $\mathrm{CCH}$} & Neoplastic CCH \\
\hline \multirow{2}{*}{$\begin{array}{l}\text { MEN } 2 \text { associated MTC } \\
\quad(n=14)\end{array}$} & \multirow[t]{2}{*}{$5-74(34.5)$} & \multirow[t]{2}{*}{$8 / 9$} & \multirow[t]{2}{*}{$11 / 14(78.6 \%)$} & \multirow[t]{2}{*}{$13 / 14(92.9 \%)$} & \multicolumn{3}{|c|}{$1 / 14(7.1 \%)$} & $10 / 14(71.4 \%)$ \\
\hline & & & & & $\begin{array}{c}\text { Focal } \\
0 / 14\end{array}$ & $\begin{array}{c}\text { Diffuse } \\
1 / 14(7.1 \%)\end{array}$ & $\begin{array}{c}\text { Nodular } \\
0 / 14\end{array}$ & \\
\hline \multirow[t]{2}{*}{ Sporadic MTC $(n=27)$} & $38-79(56.6)$ & $18 / 9$ & $1 / 27(3.7 \%)$ & $4 / 27(14.8 \%)$ & & $8 / 27(29.6 \%)$ & & $3 / 27(11.1 \%)$ \\
\hline & & & & & $\begin{array}{c}\text { Focal } \\
4 / 27(14.8 \%)\end{array}$ & $\begin{array}{c}\text { Diffuse } \\
3 / 27(11.1 \%)\end{array}$ & $\begin{array}{c}\text { Nodular } \\
1 / 27(3.7 \%)\end{array}$ & \\
\hline
\end{tabular}




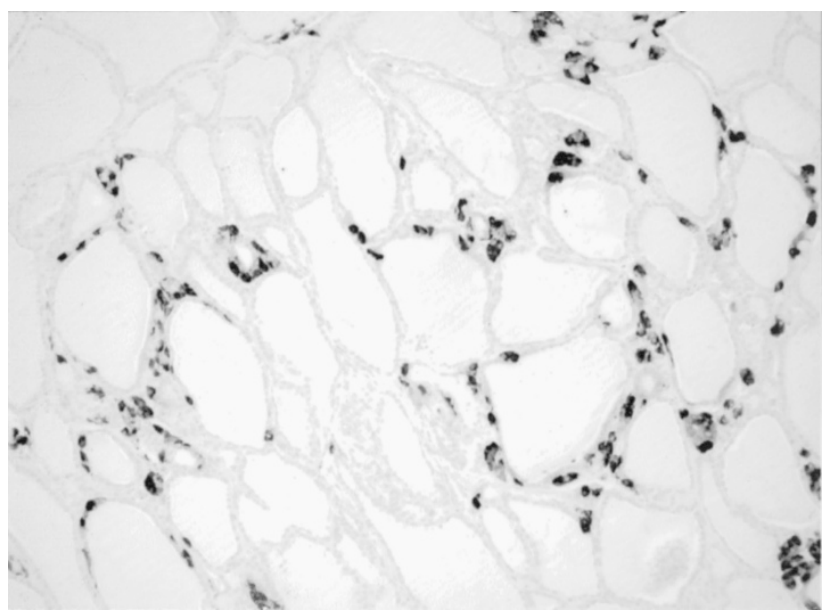

FIGURE 1. Sporadic focal C-cell hyperplasia. Thirty-three-year-old man, basal CT $=30 \mathrm{pg} / \mathrm{mL}$, stimulated CT $=112 \mathrm{pg} / \mathrm{mL}$. Immunoperoxidase reaction with anti-CT antibody; original magnification, $100 \times$

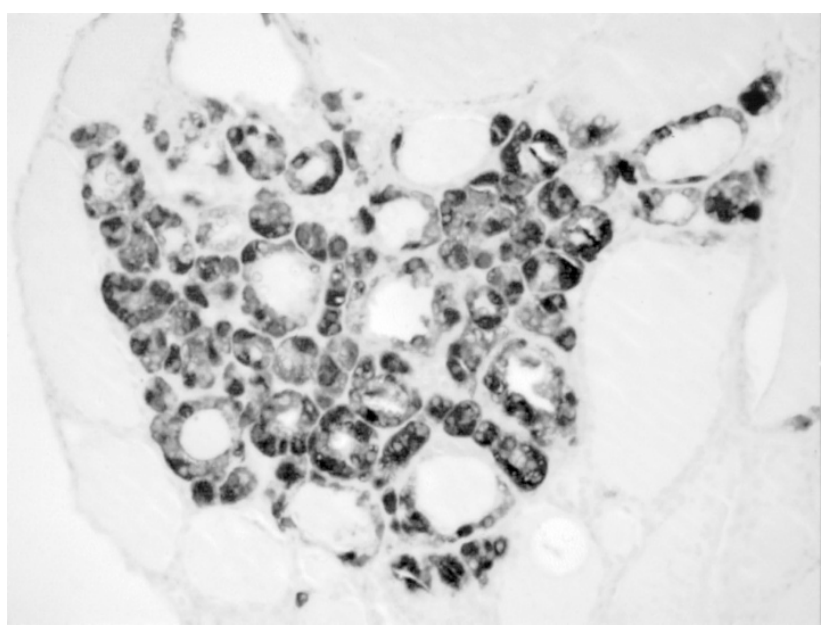

FIGURE 2. Sporadic diffuse C-cell hyperplasia. Forty-four-year-old man, basal CT $=29 \mathrm{pg} / \mathrm{mL}$, stimulated CT $=145 \mathrm{pg} / \mathrm{mL}$. Immunoperoxidase reaction with anti-CT antibody; original magnification, $200 \times$.

\section{DISCUSSION}

We present a retrospective and longitudinal series of 66 patients with a CCH and/or MTC observed in our department between 1993 and 2000, representing about $3 \%$ of all the thyroid specimens examined during this time period. In our institution, CT assay is systematic in all patients presenting with a thyroid disease. This attitude has been justified in many reports (2-4), because it allows an earlier discovery of MTC, particularly at a microMTC stage, for which prognosis is far better than that for more advanced tumors. Nonetheless, it is worth noting that in 7/66 patients of our series, the $\mathrm{C}$-cell disease (6 unique micro-MTC ranging from 0.5 to $6 \mathrm{~mm}$ in diameter, and $1 \mathrm{CCH}$ only) was a fortuitous pathological discovery, because the preoperative CT was normal (range: $3-9 \mathrm{pg} / \mathrm{mL}$, mean:

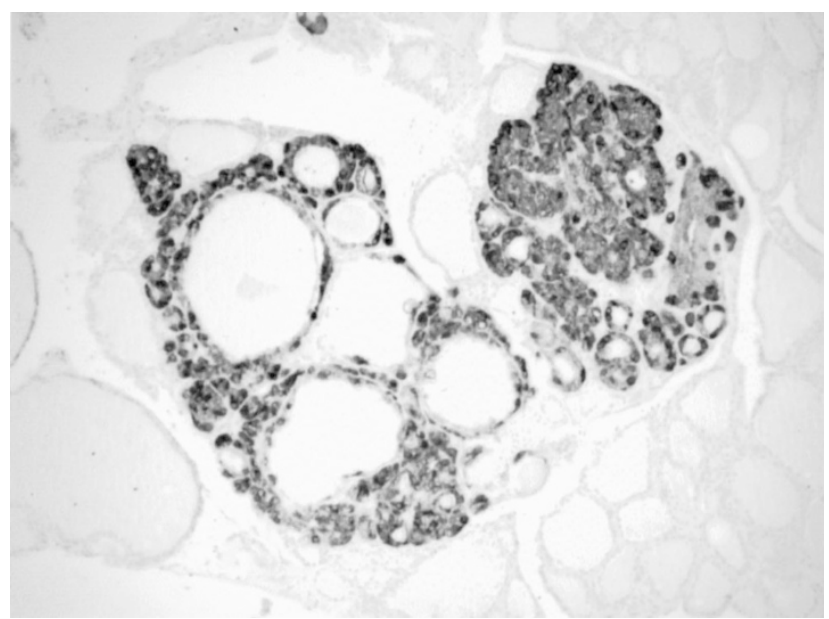

FIGURE 3. Sporadic C-cell hyperplasia, with diffuse (left) and nodular (right) pattern. Fifty-one-year-old man, basal CT $=18 \mathrm{pg} / \mathrm{mL}$, stimulated CT $=156 \mathrm{pg} / \mathrm{mL}$. Immunoperoxidase reaction with anti-CT antibody; original magnification, $100 \times$.

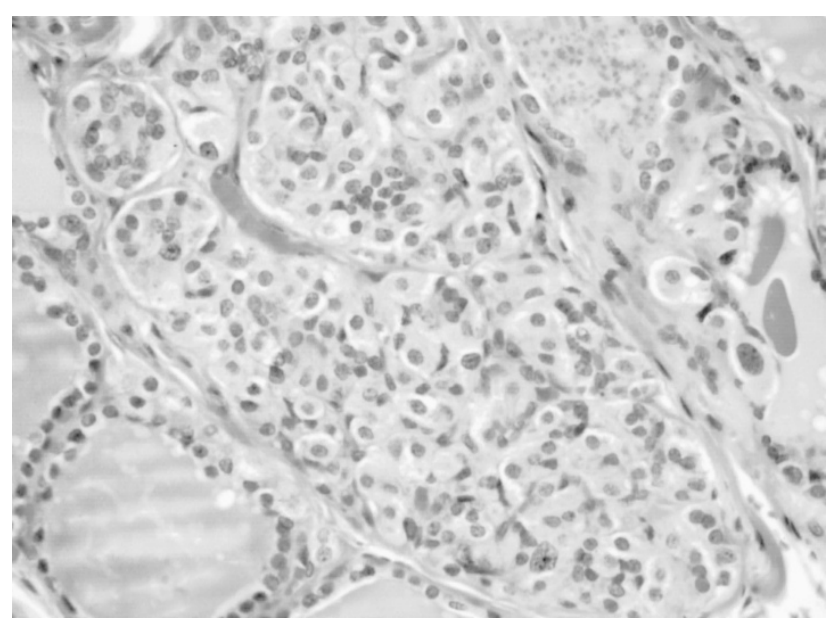

FIGURE 4. Sporadic neoplastic C-cell hyperplasia. Fifty-three-yearold man, basal CT $=14 \mathrm{pg} / \mathrm{mL}$, stimulated CT $=129 \mathrm{pg} / \mathrm{mL}$. Hematoxylin-eosin-saffron stain; original magnification, $400 \times$.

$5.1 \mathrm{pg} / \mathrm{mL})$ ). Thus, clinicians and pathologists must be aware that a normal basal CT does not definitely exclude a micro-MTC.

A side effect of systematic CT assay was the concomitant increase in patients with a final diagnosis of sporadic $\mathrm{CCH}$ only, in which thyroidectomy might be considered unjustified. In our series, a sporadic CCH only (i.e., CCH with neither familial MTC nor RET mutation) was observed in 19 male and in no female patients. This gender-associated $\mathrm{CCH}$ had a dramatic impact on the ratio of MTC in patients presenting with a fortuitous elevated basal CT (Table 2): all the women (15/15) and less than one third of the men $(8 / 26)$ presenting in this setting had an MTC. In men presenting with a mildly elevated preoperative CT level $(\leq 30 \mathrm{pg} / \mathrm{mL})$, MTC was even rarer: $4 / 21$ men with a micro-MTC (19\%) and $17 / 21$ men with $\mathrm{CCH}$ only (81\%). It was not 


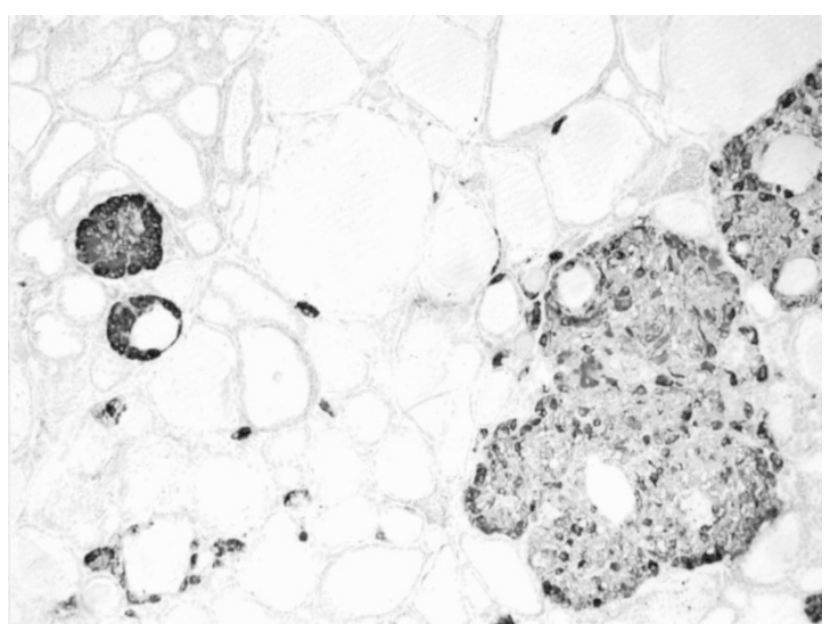

FIGURE 5. Medullary thyroid microcarcinoma (right), with adjacent neoplastic C-cell hyperplasia (left). Thirty-five-year-old man with multiple endocrine neoplasia Type 2 (fMTC), basal CT $=8 \mathrm{pg} / \mathrm{mL}$, stimulated CT $=170 \mathrm{pg} / \mathrm{mL}$. Immunoperoxidase reaction with anti-CT antibody; original magnification, $40 \times$.

possible to distinguish between these two groups before surgery (mean basal CT of 21.5 and 18.5 $\mathrm{pg} / \mathrm{mL}$, respectively). Therefore, we consider that a total thyroidectomy is still currently recommended in men presenting with a fortuitous elevated CT. This gender-associated difference was not totally unexpected: in a previous quantitative image analysis study of 42 adult normal thyroid glands, we observed that C-cell density in men was more than twice that in women. Two women (15\%) and 12 men (41\%) had CCH (15). This difference was also observed in recent studies on patients operated on for an elevated CT $(3,8)$ and may be related to the usually higher CT plasma concentration observed in healthy men (19-21). Many observations point to a role of sex-steroid hormones on CT secretion and proliferation, although one poorly understood. Most studies have focused on the role of estradiol, and very few observations are available about progesterone and testosterone effects. Estrogen substitution has proven to stimulate CT secretion in postmenopausal women (22), and CT secretion in vivo and in vitro is also influenced by estrogens and by progesterone (23). Yang et al. (24) have shown that MTC cells in culture were mildly stimulated by estrogens and inhibited by tamoxifen, thus suggesting the expression of estrogen receptors (ER) in MTC cells, but the expression of ER by normal human C-cells has not been demonstrated (25). This may suggest the role of other sex-steroid hormones and/or receptors: in this regard, Garcia-Ameijeiras et al. (26) have proposed that testosterone might influence CT secretion in man. As emphasized by Albores-Saavedra and Krueger (1), many more studies are needed to clarify the etiopathogenesis of physiologic (and particularly sex-associated) $\mathrm{CCH}$.

Many investigators have reported on clinical and pathological characteristics of sporadic versus hereditary MTC (28-32). Our study confirms that the presence of another MTC in the family, as well as tumor multifocality and bilaterality, are strongly associated with MEN 2 (Table 4). However, as stated by Kaserer et al. (7), these criteria are unreliable in the individual patient to predict whether a familial risk is present or not. First of all, the presence of a previous familial MTC may be misleading: in our series, three patients had an elevated basal $\mathrm{CT}$ and a first-degree relative with an MTC. No RET mutation was identified in both the index cases and the patients, and pathological examination of total thyroidectomy specimen revealed $\mathrm{CCH}$ only. In these three patients, a familial MTC cannot be definitely ruled out in the absence of a complete RET gene sequencing, but our opinion is that they most probably represent sporadic $\mathrm{CCH}$ cases $(>95 \%$ probability according to Brandi et al. (9)). This underlines the capacity of CT assay to identify nongenetically determined $\mathrm{CCH}$ cases $(13,33)$. We also observed a great frequency of tumor multicentricity and bilaterality in MEN 2 cases $(92.9 \%$ and $78.6 \%$, respectively) in comparison with sporadic cases ( $14.8 \%$ and $3.7 \%$, respectively). Nonetheless, it is worth noting that on the basis of these criteria, $4 / 27$ cases would have been erroneously considered as hereditary MTC, and 1/14 patients as a sporadic MTC.

For many years, the identification of a $\mathrm{CCH}$ in a thyroid containing an MTC has been considered an indicator of MEN 2 (30, 31). However, as we already observed (15), $\mathrm{CCH}$ is a rather common finding in adult thyroids, and lacks specificity as a MEN 2 predictor. In this series, we identified a $\mathrm{CCH}$ in $11 / 27(41 \%)$ sporadic and in 11/14 (79\%) MEN 2 cases. Perry et al. (11) have proposed morphological criteria to distinguish between physiological and

TABLE 5. C-Cell Quantification among 47 Patients with $\mathrm{CCH}$

\begin{tabular}{|c|c|c|c|c|}
\hline & \multicolumn{3}{|c|}{ Physiologic CCH $(n=29)$} & \multirow{2}{*}{$\begin{array}{l}\text { Neoplastic CCH } \\
\quad(n=18)\end{array}$} \\
\hline & Focal $(n=9)$ & Diffuse $(n=14)$ & Nodular $(n=6)$ & \\
\hline Peak C-cell number per LPF* & $70-250($ mean $=134)$ & $100-340($ mean $=183)$ & $170-360($ mean $=250)$ & $130-390($ mean $=262,3)$ \\
\hline $\begin{array}{l}\text { Number of LPF containing } \\
\text { more than } 50 \text { C-cells* }\end{array}$ & $3-11 \quad($ mean $=6.0)$ & $3-24 \quad($ mean $=11.4)$ & 8-34 $($ mean $=20.0)$ & $2-29 \quad($ mean $=11.4)$ \\
\hline
\end{tabular}


neoplastic $\mathrm{CCH}$. The former requires immunohistochemistry and quantitative analysis to be identified with certainty. It has been reported with a high frequency $(\leq 69 \%)$ in normal adults (34) and in association with various conditions such as chronic lymphocytic thyroiditis, in the vicinity of follicular thyroid tumors, or in association with hypergastrinemia or hyperparathyroidism (1), and it has no documented malignant potential. The later is mainly recognized on cytological atypia, considered to reflect preneoplastic alterations associated with MEN 2. This is supported by a recent study by Diaz-Cano et al. (27), showing that MEN 2A-associated $\mathrm{CCH}$ had genetic and kinetic characteristics consistent with an intraepithelial neoplasia. Since 1996, a number of investigators have agreed that these two conditions actually represented different states in C-cell pathology $(3,7,8,12)$. Because the term "neoplastic $\mathrm{CCH}^{\circ}$ " seems contradictory in itself, several alternative denominations have been proposed, such as "in situ-MTC" $(12,28,29)$, "thyroid intraepithelial neoplasia of C-cells" (7), or "Ccell intraepithelial neoplasia" (CCIN). We agree with this opinion but employed the term neoplastic $\mathrm{CCH}$ in this study because it is currently the most widely used.

The results of C-cell quantification in our series are summarized in Table 5. There was an increase in C-cell density as CCH progressed from focal to diffuse and from diffuse to nodular subtypes. On the other hand, there was no significant difference between C-cell density in neoplastic $\mathrm{CCH}$ and nodular physiologic $\mathrm{CCH}$. Moreover, preoperative CT levels did not correlate with $\mathrm{CCH}$ subtypes. These data confirm that it is inappropriate, either from a practical or from a theoretical point of view, to try to distinguish between physiological and neoplastic $\mathrm{CCH}$ on quantitative grounds. In the first report by Perry et al. (11), the investigators identified neoplastic $\mathrm{CCH}$ in MEN 2 patients only. However, Scheuba et al. (8) have identified neoplastic CCH in $15 / 39$ sporadic $\mathrm{CCH}$ cases, and a recent study by Kaserer et al. (7) reported the presence of neoplastic $\mathrm{CCH}$ in association with sporadic micro-MTC in 6/34 cases, suggesting that neoplastic $\mathrm{CCH}$ could also be the precursor of some sporadic MTC. We found neoplastic CCH in 10/14 (71.4\%) MEN 2 cases but also in $8 / 46(17.4 \%)$ sporadic cases. When associated with sporadic MTC (3/27 cases, 11.1\%), neoplastic CCH was found close to infiltrative MTC, displaying the same kind of cytological atypia, a fact that may be an argument for a lineage between both lesions. As suggested by Kaserer et al., we think that the first reports on the absence of $\mathrm{CCH}$ associated with sporadic MTC might have been biased by the important size of tumors, most of the thyroid parenchyma being replaced by tumor growth (3). As CT assays allow the earlier discovery of sporadic MTC, often at a micro-MTC stage, it could soon become evident that sporadic MTC may also develop from neoplastic $\mathrm{CCH}$, at least in a certain number of cases. On the other hand, it is worth noting that we found no neoplastic $\mathrm{CCH}$ in the vicinity of sporadic MTC in women (18 cases). Thus, alternative tumorigenesis pathways might also exist that do not necessitate a neoplastic $\mathrm{CCH}$ stage.

In conclusion, our study confirms that clinical and pathological characteristics often associated with hereditary MTC are currently overtaken by $R E T$ gene sequencing in most instances, as this test does not lead to false-positive conclusions. RET gene analysis should be proposed to each patient presenting with an MTC, and probably with a neoplastic $\mathrm{CCH}$, for which we prefer the term $\mathrm{C}$-cell intraepithelial neoplasia. This condition was mostly observed in hereditary MTC, but we also identified it in a number of sporadic cases. In this regard, we postulate that neoplastic $\mathrm{CCH}$ might be the precursor of a certain number of sporadic MTC. Moreover, our study reveals that in patients presenting with a fortuitous mild hypercalcitoninemia (i.e., CT $\leq 30$ $\mathrm{pg} / \mathrm{mL}$ ), the MTC risk is fivefold lesser in men (19\%) than in women $(100 \%)$. This emphasizes the great male prevalence of $\mathrm{CCH}$ only, which requires further investigations to be identified before an unjustified thyroidectomy.

\section{REFERENCES}

1. Albores-Saavedra JA, Krueger JE. C-cell hyperplasia and medullary thyroid microcarcinoma. Endocr Pathol 2001;12: 365-77.

2. Nicolli P, Wion-Barbot N, Caron P, Henry J-F, De Micco C, Saint-André J-P, et al. Interest of routine measurement of serum calcitonin: study in a large series of thyroidectomized patients. J Clin Endocrinol Metab 1997;82:338-41.

3. Kaserer K, Scheuba C, Neuhold N, Weinhäusel A, Vierhapper H, Haas OA, et al. C-cell hyperplasia and medullary thyroid carcinoma in patients routinely screened for serum calcitonin. Am J Surg Pathol 1998;22:722-8.

4. Hahm JR, Lee MS, Min YK, Lee MK, Kim KW, Nam SJ, et al. Routine measurement of serum calcitonin is useful for early detection of medullary thyroid carcinoma in patients with nodular thyroid diseases. Thyroid 2001;11:73-80.

5. Beressi N, Campos JM, Beressi JP, Franc B, Niccoli-Sire P, Conte-Devolx B, et al. Sporadic medullary microcarcinoma of the thyroid: a retrospective analysis of eighty cases. Thyroid 1998;8:1039-44.

6. Guyétant S, Dupré F, Bigorgne JC, Franc B, Dutrieux-Berger $\mathrm{N}$, Lecomte-Houcke $\mathrm{M}$, et al. Medullary thyroid microcarcinoma: a clinicopathologic retrospective study of 38 patients with no prior familial disease. Hum Pathol 1999;30:957-63.

7. Kaserer K, Scheuba C, Neuhold N, Weinhausel A, Haas OA, Vierhapper $\mathrm{H}$, et al. Sporadic versus familial medullary thyroid microcarcinoma: a histopathologic study of 50 consecutive patients. Am J Surg Pathol 2001;25:1245-51.

8. Scheuba C, Kaserer K, Weinhausl A, Pandev R, Kaider A, Passler C, et al. Is medullary thyroid cancer predictable? A prospective study of 86 patients with abnormal pentagastrin tests. Surgery 1999;126:1089-96. 
9. Brandi ML, Gagel RF, Angeli A, Bilezikian JP, Beck-Peccoz P, Bordi C, et al. Guidelines for diagnosis and therapy of MEN type 1 and type 2. J Clin Endocrinol Metab 2001;86:5658-71.

10. Lips CJ. Clinical management of the multiple endocrine neoplasia syndromes: results of a computerized opinion poll at the Sixth International Workshop on Multiple Endocrine Neoplasia and von Hippel-Lindau disease. J Intern Med 1998;243:589-94.

11. Perry A, Molberg K, Albores-Saavedra J. Physiologic versus neoplastic C cell hyperplasia of the thyroid. Separation of distinct histologic and biologic entities. Cancer 1996;77:750-6.

12. Hinze R, Holzhausen HJ, Gimm O, Dralle H, Rath FW. Primary hereditary medullary thyroid carcinoma-C-cell morphology and correlation with preoperative calcitonin levels. Virchows Arch 1998;433:203-8.

13. Barbot N, Calmettes C, Schuffenecker I, Saint-Andre JP, Franc B, Rohmer V, et al. Pentagastrin stimulation test and early diagnosis of medullary thyroid carcinoma using an immunoradiometric assay of calcitonin: comparison with genetic screening in hereditary medullary carcinoma. J Clin Endocrinol Metab 1994;78:114-20.

14. Wion-Barbot N, Schuffenecker I, Niccoli P, Conte-Devolx B, Lecomte P, Houdent C, et al. Results of the calcitonin stimulation test in normal volunteers compared with genetically unaffected members of MEN 2A and familial medullary thyroid carcinoma families. Ann Endocrinol (Paris) 1997;58: 302-8.

15. Guyétant S, Rousselet MC, Durigon M, Chappard D, Franc B, Guérin $\mathrm{O}$, et al. Sex-related C-cell hyperplasia in the normal human thyroid: a quantitative autopsy study. J Clin Endocrinol Metab 1997;82:42-7.

16. Guyétant S, Wion-Barbot N, Rousselet M-C, Franc B, Bigorgne J-C, Saint-André J-P. C-cell hyperplasia associated with chronic lymphocytic thyroiditis: a retrospective quantitative study of 112 cases. Hum Pathol 1994;25:514-21.

17. De Lellis RA. C cell hyperplasia. In: Rosai J, Carcangiu ML, De Lellis RA, editors. Atlas of tumor pathology. 3rd series. Fascicle 5. Tumors of the thyroid gland. Washington, D.C.: Armed Forces Institute of Pathology; 1992.

18. McDermott MB, Swanson PE, Wick MR. Immunostains for collagen type IV discriminate between C-cell hyperplasia and microscopic medullary carcinoma in multiple endocrine neoplasia, type 2a. Hum Pathol 1995;26:1308-12.

19. Inoue S, Yokoyama S, Nakayama I, Noguchi S. An immunohistochemical study of calcitonin-containing cells in benign and malignant thyroid lesions. Acta Pathol Jpn 1990;40:18792.

20. Van Lathem JJ, Vermaak WJ, Kuyl JM, Mollentze W, Jansen S, Wolmarans L, et al. Experience with a provocative test of calcitonin release as a prospective screening for preclinical medullary thyroid carcinoma in MEN type 2A family members. J Clin Lab Anal 1992;6:384-90.
21. Suzuki H. Calcitonin levels in normal individuals with new highly sensitive chemiluminescent enzyme immunoassay. J Clin Lab Anal 1998;12:218-22.

22. Naveh-Many T, Almogi G, Livni N, Silver J. Estrogen receptors and biologic response in rat parathyroid tissue and $\mathrm{C}$ cells. J Clin Invest 1992;90:2434-8.

23. Greenberg C, Kukreja SC, Bowser EN, Hargis GK, Henderson WJ, Williams GA. Effects of estradiol and progesterone on calcitonin secretion. Endocrinology 1986;118:2594-8.

24. Yang K, Pearson CE, Samaan NA. Estrogen receptor and hormone responsiveness of medullary thyroid carcinoma cells in continuous culture. Cancer Res 1988;48:2760-3.

25. Frolich A, Christensen L, Andersen J. Estrogen receptors appear undetectable in the C-cells of the human thyroid gland. Bone 1990;11:393-6.

26. Garcia-Ameijeiras A, De La Torre W, Rodriguez-Espinosa J, Perez-Perez A, De Leiva A. Does testosterone influence the post-stimulatory levels of calcitonin in normal men? Clin Endocrinol 1987;27:545-52.

27. Diaz-Cano SJ, de Miguel M, Blanes A, Tashjian R, Wolfe HJ. Germline RET 634 mutation positive MEN 2A-related C-cell hyperplasias have genetic features consistent with intraepithelial neoplasia. J Clin Endocrinol Metab 2001;86:3948-57.

28. LiVolsi VA. C cell hyperplasia/neoplasia [editorial]. J Clin Endocrinol Metab 1997;82:39-41.

29. Krueger JE, Maitra A, Albores-Saavedra J. Inherited medullary microcarcinoma of the thyroid: a study of 11 cases. Am J Surg Pathol 2000;24:853-8.

30. Ekblom M, Valimaki M, Pelkonen R, Jansson R, Sivula A, Franssila K. Familial and sporadic medullary thyroid carcinoma: clinical and immunohistological findings. Q J Med 1987;65:899-910.

31. Franc B, Akrwight A, Caillou B, Dutrieux-Berger N, Floquet J, Houcke-Lecomte M, et al. Expressions morphologiques des carcinomes médullaires de la thyroïde (CMT) dans les formes familiales. In: Calmettes C, Guliana JM, editors. Medullary thyroid carcinoma. Colloque INSERM/John Libbey Eurotext Ltd; 1991. p. 159-61.

32. LiVolsi VA. Medullary carcinoma. In: Bennington JL, editor. Surgical pathology of the thyroid. Vol 22. Major problems in pathology. Philadelphia, PA: Saunders; 1990.

33. Marsh DJ, McDowall D, Hyland VJ, Andrew SD, Schnitzler M, Gaskin EL, et al. The identification of false positive responses to the pentagastrin stimulation test in RET mutation negative members of MEN 2A families. Clin Endocrinol (Oxf) 1996;44:213-20.

34. Santeusanio G, Iafrate E, Partenzi A, Mauriello A, Autelitano F, Giusto Spagnoli L. A critical reassessment of the concept of C-cell hyperplasia of the thyroid. Appl Immunohistochem 1997;5:160-72. 